\title{
Occurrence of Xanthomonas axonopodis pv. allii causing onion bacterial blight in Minas Gerais State, Brazil
}

\author{
Igor Souza Pereira ${ }^{1} \&$ Nilvanira Donizete Tebaldi ${ }^{2}$
}

${ }^{1}$ Instituto Federal de Educação, Ciência e Tecnologia do Triângulo Mineiro (IFTM), Campus Uberlândia, Faz. Sobradinho, S/N, Zona Rural, CEP 38400-970, CP 1020, Uberlândia, MG, Brazil; 2Instituto de Ciências Agrárias, Universidade Federal de Uberlândia, Av. Amazonas s/n, Bloco 4C127, Campus Umuarama, CEP 38.400-902, Uberlândia, MG, Brazil

Corresponding author: Nilvanira Donizete Tebaldi, e-mail: nilvanira@iciag.ufu.br Data de chegada: 30/07/2013. Aceito para publicação em: 25/09/2013.

Onion bacterial blight, caused by Xanthomonas axonopodis pv. allii Roumagnac, Gagnevin, Gardan, Sutra, Manceau, Dickstein, Jones, Rott \& Pruvost 2003 (ROUMAGNAC et al. International Journal of Systematic and Evolutionary Microbiology, v.54, p.15-24, 2003), was first described in São Paulo State, Brazil, in 1987 (RODRIGUES NETO et al. Summa Phytopathologica, v.13, p.10, 1987).

In March 2013, Bella Dura and Andromeda onion hybrids grown under irrigation system in a field in Santa Juliana, Minas Gerais State, Brazil, had water-soaked spots on their leaves with typical symptoms of onion bacterial blight (Figure 1). The symptoms start as small water-soaked spots (1-2 mm diameter), which extend, coalesce and become necrotic. No symptoms were observed in the bulbs of infected plants. Bacterial exudation from infected leaf tissue was observed under the microscope; then, the pathogen was isolated on NutrientAgar medium. Bacterial identification was performed and the following characteristics were determined (SCHAAD et al. Laboratory guide for identification of plant pathogenic bacteria. St. Paul. APS, 2001): colonies grown on 523 and YDC culture media after 2-3 days, at 28 ${ }^{\circ} \mathrm{C}$, were yellow, convex, round and mucoid Gram-negative, obligate aerobes using glucose oxidatively, negative to asparagine as unique source of carbon and nitrogen, King B-negative, oxidase-negative, catalase-positive, positive when grown at $40^{\circ} \mathrm{C}$, positive to starch hydrolysis, positive to gelatin liquification, negative to acid production from arabinose, negative to utilization of glycerol, and positive to hypersensitivity reaction on tomato cv. Santa Clara. For the pathogenicity test, five Bella Dura onion hybrid plants (approximately 60 days old) were inoculated by means of bacterial suspension spraying at $\left.10^{9} \mathrm{CFU} \mathrm{mL}-1 \mathrm{OD}_{550}=0.5\right)$. Control onion plants were sprayed with saline solution at $0.85 \%$. The plants were maintained in a moist chamber for $24 \mathrm{~h}$ before and after inoculation in a greenhouse. After five days, the symptoms were observed as water-soaked leaf spots, which extended and eventually coalesced, resulting in leaf blight, from which the bacteria was reisolated. No symptoms were observed on control onion plants. These characteristics led to the identification of

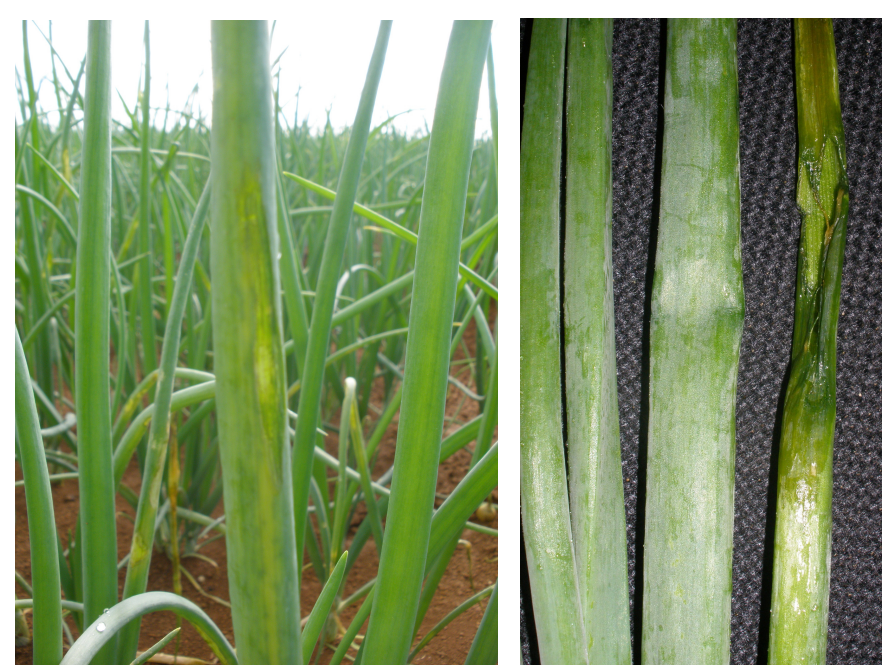

Figure 1. Symptoms of bacterial blight on onion leaves, caused by Xanthomonas axonopodis pv. allii.

the bacterium as $X$. axonopodis pv. allii, the causal agent of onion bacterial blight. The correct characterization and identification of plant pathogenic bacteria can promote adequate disease management in the field and prevent the inappropriate use of fungicide for control. This is the first report of $X$. axonopodis pv. allii causing bacterial blight on onion in Minas Gerais State, Brazil. The strain was deposited in the phytopathogenic bacterial collection of the Agrarian Sciences Institute, Uberlândia Federal University, and codified as UFU E5.

\section{Acknowledgments}

The authors are indebted to Engineer Agronomist Mario K. Kido and Ms. Tânia M. Toyota Kido for supplying the onion plants for inoculation. 